Article

\title{
Forensics at the Port: Can Diagnostic Testing Benefit Trade?
}

\author{
Savannah W. Gleim *(D), Richard S. Gray $(1)$ and Stuart J. Smyth (i) \\ Department of Agricultural and Resource Economics, University of Saskatchewan, \\ Saskatoon, SK S7N 5A8, Canada; richard.gray@usask.ca (R.S.G.); stuart.smyth@usask.ca (S.J.S.) \\ * Correspondence: savannah.gleim@usask.ca
}

\section{check for} updates

Citation: Gleim, S.W.; Gray, R.S.; Smyth, S.J. Forensics at the Port: Can Diagnostic Testing Benefit Trade? Sustainability 2021, 13, 106. https: / /dx. doi.org/10.3390/su13010106

Received: 25 November 2020 Accepted: 22 December 2020 Published: 24 December 2020

Publisher's Note: MDPI stays neutral with regard to jurisdictional claims in published maps and institutional affiliations.

Copyright: () 2020 by the authors. Licensee MDPI, Basel, Switzerland. This article is an open access article distributed under the terms and conditions of the Creative Commons Attribution (CC BY) license (https: / creativecommons.org/ licenses/by/4.0/).

\begin{abstract}
A growing pool of genomic knowledge and remarkable reductions in the cost of genetic sequencing is revolutionizing the identification of plant pathogens and phytosanitary risks. This article examines available technologies of plant testing for genetics, residues, and contamination that can be imposed at port locations for the trade of bulk commodity crops. Access and deployment of lower-cost detection technologies could fundamentally change phytosanitary practices with potential consequences for agricultural trade. Investment in testing for the presence of transgenic dockage or plant and soil diseases will likely decrease time and arbitration costs. Implementation of diagnostics testing could not only protect the exporters' position, but it could also lead to future implications of trusted trade or higher standards of phytosanitary policy. The lack of rigorous export testing creates the opportunity for trade protectionist countries to claim that commodity imports fail to meet import standards, which can either lower the price or result in shipment rejection. The failure of commodity shipments to comply with import thresholds is a regular occurrence, yet resolutions are achieved that do not disrupt international trade. This rise in the ability to accurately test for pathogen detection provides the opportunity for safer commodity trade, but also the rise in protectionism.
\end{abstract}

Keywords: adventitious presence; diagnostics; low-level presence; pathogen; phytosanitary risk; trade

\section{Introduction}

Through the advancements of science and global trade, agriculture has expanded past the traditional 19th-century markets. Over the past 100 years, the agricultural landscape has changed, presenting producers, consumers and nations with new technologies and food options [1]. Alongside the advancements of safer pesticides, machinery, plant breeding, and land management practices, there have been improvements in pathogen testing. Similar to the efforts to prevent the spread of COVID-19, greater effort has been implemented to protect global agriculture from its occurrence and spread. In the ever-rapid pace of increased agricultural trade, there is a growing importance for advanced detection of pathogens and diseases in order to help ensure that countries are not importing commodities that contain pathogens or diseases that could end up costing governments significant amounts of money to control.

For much of the world, scientific contributions in agriculture have led to the commercialization of new crop varieties and increased global access to agricultural commodity trade [2]. The bolstered trade allows nations and regions to specialize in crop development, resulting in economic growth due to increased market access. Specialized markets lead those nations to protect their investments and economic gains that come with the global trade of cash crops. For instance, Hawaii specializes in the production of several tropical fruits. In the 1990s, Hawaiian papaya production was nearly destroyed by the papaya ringspot virus (PRSV). Fortunately, Hawaiian researchers were able to develop varieties that were resistant to PRSV before their papaya production specialization was lost [3]. As a result, much of the Hawaiian papaya production was saved, the quality was retained, and the risk of spreading the virus globally was significantly reduced. However, such solutions are not always found or adopted. While the innovative technology of PRSV-resistant 
papaya was successfully adopted and accepted by consumers and policy makers, not all crops have a plant breeding solution.

In trade, each nation has an acceptable level of risk that they are willing to accept with the trade they conduct, particularly as each nation imports a different bundle of goods [4]. The exporting nation bears the risk that an exported product will not meet the phytosanitary regulations and certifications of the importing nation. Both requirements must be met, as if importers were to detect an exogenous phytosanitary pathogen, the importing nation could impose the precautionary principle, preventing the import or deny market access to protect their industry, environment, and/or consumers. While this is the extreme case, the importer could simply reject the shipment, the increased security of national agriculture, the environment and consumer and livestock health, poses the risk of greater trade restrictions being imposed due to the presence of a pathogen [5]. However, these rejections come at a cost - in global agricultural markets, any major detected risks and rejections at the import position can lead to global news and can often influence stock prices, which trickles through the supply chain, frequently impacting producers the most.

This article investigates the question of whether the application of biotechnological and diagnostic tests before export, benefit trade and health, preventing contamination from pathogens and diseases or are being applied for political reasons to protect domestic production? With a focus on the Canadian and US markets, this article addresses instances where exports were rejected due to a lack of transparency to ensure that all phytosanitary certifications were being met. This article assesses the most logical supply chain location to test exports, what pathogen diagnostic technologies can be utilized, and the potential impact that these diagnostic tests could have on trade and domestic supply chains if they become mandatory.

\section{Phytosanitary Trade Issues}

Concerns about phytosanitary issues, plant disease or commodity contamination, can stop a trade shipment, which is why trade agreements, safety standards, off-type thresholds and protocols exist to protect safe international trade [6]. As trade liberalization increased throughout the 20th century, it resulted in numerous pathogens being introduced to importing nations, which plateaued once these nations began to introduce biosecurity risk assessments and regulations to limit their spread [7]. Since international commodity trade functions daily, there are agreements and policies in place for off-type thresholds. Off-types might be as simple as kernels/seeds of other crop varieties, such as a bit of canola in a wheat shipment or flax in a barley shipment, none of which constitutes a safety issue for exporter or importer. Thresholds are also set for more noxious or invasive comingling, which includes levels for weed seeds, insect fragments and extraneous filth. These do constitute concerns, although exporters and importers realize that international commodity trade is not capable of functioning with zero-percent threshold levels for such undesirable comingling. In some instances, off-types can be the low-level presence (LLP) of varieties of genetically modified (GM) crops that specific importers wish to avoid or the adventitious presence (AP) of a new crop variety that has not received import approval in the importing nation [8].

While there are no definitive data, the commodity trade industry has indicated that most weeks (if not days) the industry detects LLP of some off-type threshold violation in shipments and has to decide how to manage the flows. This is performed either by diverting the shipment or by greater blending to reduce any measurable amounts below the regulatory thresholds in the destination market.

In 2014, the Food and Agriculture Organization (FAO) surveyed nations about GM crops, including LLP/AP incidents, and the importance of factors contributing to the trade risks posed by LLP/AP [9]. Of the 64 participating nations, 54\% indicated they have no LLP / AP thresholds for GM crops, reducing the likelihood of market disruptions. Onethird of respondents indicated that their nation has defined specific thresholds (mostly for feed). Furthermore, slightly less than half of the respondents indicated that they have 
the full technical capacity to detect or quantify genetically modified organisms (GMOs) according to Codex guidelines. The survey revealed that approximately 20 nations and the EU reported at least one LLP/AP event in the last 10 years.

A closer examination of the reported LLP events reveals that they involved shipments of canola, flax, corn, soybeans and papaya from the US, Canada and Brazil, and imported into Argentina, Brazil, various EU member states, Iran, Japan, Madagascar, Namibia, New Zealand and Norway. The materials were detected and reported by a mix of actors, including shippers, technology developers, competent national regulatory authorities, Greenpeace and third-party auditors. Depending on the market and the trait, the offending shipments were diverted to biofuel production, rejected, returned or diverted to other markets, held until approved or destroyed. All of which pose a cost to both importers and exporters.

Depending on the causes and nature of the LLP and AP events, there are different ways of measuring the scale of the phytosanitary issue. Regulators and trade policy frame the problem as a state-to-state conflict while most in the grain/crop trade see it as a day-today challenge to maintain and manage product differentiation [6]. Depending on which approach one takes, the scale and scope of the challenge vary widely.

When a phytosanitary issue arises, it can cause domestic issues between producing regions, states or provinces. For instance, a South Australian farm owned by Sparnon was found to be contaminated with bacterial wilt following the supply of infected seed potatoes by Apand, a potato chip manufacturer [10]. At this time, importing infected seed potatoes into Southern Australia by Apand was illegal. As a result, Sparnon suffered property damage from the lost profits they would otherwise have received from the sale of potatoes and the costs of eliminating the disease from their land.

As a South Australia farm, the Sparnon's land was on the border with Western Australia, a state whose regulations prohibited the sale of potatoes if grown on a property or processed with other potatoes grown within $20 \mathrm{~km}$ of a property, infected with bacterial wilt during the previous five years. The Perres were a group of potato producers on properties between 2 to $3 \mathrm{~km}$ around the Sparnon's farm. The disease did not spread to their properties and they had no relationship with Sparnon. However, their businesses were affected by the damage to Sparnons' property [10]. Upon the outbreak of the disease on the Sparnons' property, the Perres lost their export market to Western Australia. Due to Western Australia's phytosanitary regulation to ensure food safety and prevent further environmental contamination, the entire region in which the Sparnons lived lost its exportapproved status even though the disease did not spread beyond the Sparnons' property.

The detection of a sanitary or phytosanitary (SPS) concern in international trade can have lasting effects. Each nation is allowed to have its own science-based SPS standards, therefore requiring exporters to meet the standards in place to facilitate trade. In many cases, this means the exporting nation needs to ensure no threshold is exceeded, but it could also be ensuring that no AP of a non-registered crop variety or chemical residue is present. The result of an AP event can cause the threshold in a crop to drop to $0 \%$, potentially rejecting the delivery at import. In such a case, the importing nation has the right to protect their industries, environment and consumers. It is this difference in national approvals and SPS standards which can complicate trade, as what is deemed safe or an acceptable threshold in one nation can be too high or an illegal AP in another nation.

Currently, advancements in detection technology have improved the diagnostic tools to track LLP, chemical residues and off-type contamination. This has allowed nations to set stricter limitations and higher standards for what they deem to be SPS related issues and what is acceptable of imports. In addition to being able to impose higher standards of detection for SPS risks, there is a gray area of SPS and phytosanitary policies that can be utilized or manipulated for political benefit. While SPS policies should be enforced due to scientific evidence, importing nations can impose policies through the precautionary principle to avoid potential harm, even without evidence of risk. 
A recent example of this very situation is China's attempt to lower thresholds regarding canola exports from Canada. Blackleg is a plant pathogen that can affect canola production. Spores from the pathogen exhibit themselves as residue on the harvested canola. China imports canola for crushing, and therefore the risk of blackleg spreading in China is extremely low [11]. Crushing the canola effectively destroys the disease, so there are extremely low possibilities of the disease being transmitted as a processed oil from one canola producing region, such as Canada, to an importing country.

Before 2016, the threshold for LLP canola exports from Canada to China allowed for a $2.5 \%$ threshold for off-types to be present in shipments. In early 2016, China announced its intention to lower this to $1 \%$ as part of protective measures to ensure the potential was minimized for blackleg to be transferred from Canada to China through canola shipments [12]. The Canola Council of Canada's president, Patti Miller indicated that private "research that we have done on this issue, which was done jointly and with independent researchers, shows that there is no reduction in risk from bringing current levels of dockage down to 1 per cent" [13]. China intended for the lower threshold to come into effect as of 1 September 2016. However, a face-to-face meeting between the leaders of both countries resulted in an agreement to engage in further discussions and that the lower threshold implementation date was pushed back until 31 December 2019. China's threat would have restricted Canadian access to China's canola import sales of $\$ 2$ billion through new regulation regarding dockage of impurities over blackleg [14]. Given the research indicating that reduced thresholds have no impact on mitigating the spread of blackleg, it would appear that in this instance that China attempted to manipulate SPS standards for their non-science-based trade reasons.

The ability to manipulate SPS standards to impose trade power and pressure was again been demonstrated between Canada and China in 2019, after China revoked the import license of Canadian canola from Richardson International Ltd. in March, and Viterra soon after. According to the Chinese embassy, the import license was revoked for safety precautions, as there had been four incidences of pests in Canadian-imported canola since January 2019 [15]. Canada's Canadian Food Inspection Agency has not found sciencebased evidence to support the safety precautionary measures. At this same time, there are tensions between Canada and China over the arrest of Huawei CFO, Meng Wanzhou. Such tensions can give way to each nation imposing sanctions or trade barriers, placing economic pressures on the opposition in efforts to attain political objectives [16]. While it cannot be confirmed that the imposed precautionary policy to ban Canadian canola imports is a result of bigger political issues, it also does not appear to be rooted in science. It is obvious that the game of politics knows when to impose trading pressures and 'precautionary' decisions to communicate and help to resolve a bigger issue. The downfall is that those involved in the production of those traded goods can fall victim to greater trading pressures and policies.

It seems evident that under current SPS policies and growing abilities to test and restrict trade due to phytosanitary risks, there are potential benefits to the exporter to begin or further improve their SPS diagnostic testing before exporting.

\section{Economic Theory}

In the case of agriculture, nations benefit from the access to free trade offers. If a nation can produce a large enough quantity that is low in price, while still being a safe and quality product, open borders can be profitable to the agriculture industry. However, when safety qualities begin to waiver, open borders can soon become closed, but to whose disadvantage? When an incoming product threatens SPS standards of the importing nation, the risk of free trade for particular commodities may be too great to maintain free trade. Under the risks of SPS, what is the best decision for the importing nation to make to protect their future crops, livestock and consumer safety?

First, consider the case where free trade exists between two nations and no disease exists. The equilibrium in the importing nation is shown in Figure 1. In this case, the total 
supply, $S_{T}$, is made up of domestic production, $S_{D}$, and the foreign supply, $S_{F}$, intersects with domestic demand at point $A$, with a price of $P_{0}$ and a total quantity of $Q_{0}$.

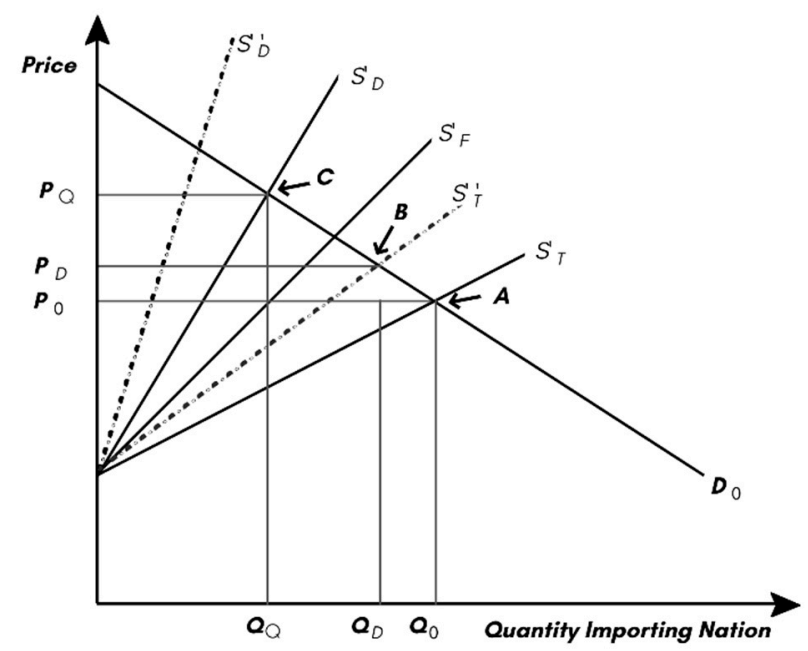

Figure 1. The impact of demand reducing phytosanitary event and quarantine measures. Source: Authors.

If the imported product creates a phytosanitary issue for the importing nation, such as a crop disease, that will pivot the domestic supply to $S_{D}^{\prime}$, there will be a reduction in total supply to $S_{T}^{\prime}$, which will intersect demand at point $B$ at a price of $P_{D}$ and quantity of $Q_{D}$. The disease will leave the domestic consumers worse off due to a higher price, foreign suppliers will be better off because they can sell at a higher price. Domestic producers will generally be worse off, now disadvantaged by the disease but receiving a higher price. The disease reduces the total economic surplus by the size of the wedge between $S_{T}^{\prime}$ and $S_{T}$ below the demand curve.

Now consider the case where the importing nation detects disease in an imported product and chooses to protect their domestic production through a quarantine measure that blocks all imports from the disease present on imports. In this case, the total supply becomes $S_{D}$, which intersects the demand curve at point $C$, at the price of $P_{Q}$ and quantity of $Q_{Q}$. The domestic producers are far better off. Not only are they protected from disease, but they are also protected from imports. The quarantine will typically increase price relative to the disease outcome, except when the importing country is 'large' in both global production and demand, and the potential disease costs are very large. In this exceptional case, the $P_{D}$ would be greater than $P_{Q}$. In a more general case, the quarantine measure will result in a higher price for the domestic nation formerly importing, i.e., $\left(P_{Q}>P_{D}\right)$.

The overall welfare impacts of the quarantine measure are ambiguous, as the importing country must give its gains from trade to avoid the disease costs. What is clear is that domestic producers that import will always be better off with quarantine measures and act with self-interest to lobby for this protection regardless of the disease costs. If governments are either supporting farm income or need farm votes there will be a tendency to overuse quarantine measures. If genomic tools reduce cost and detection thresholds, increased protection will accompany these new tools.

Sanitary or health (human or animal) issues can induce consumption related costs, either imposing external health costs or reducing market demand or both. In the case of a pure consumption related externality, market demand is unaffected but taxpayers or non-purchasers bear the entire cost of the sanitary issue, leaving market participants unaffected by the event. This equilibrium is shown as point A in Figure 2. 


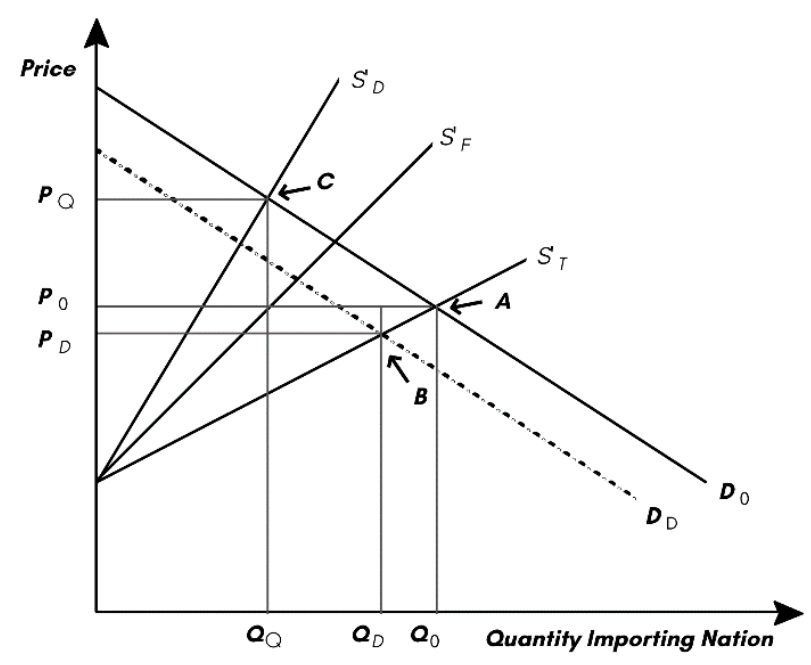

Figure 2. The impact of demand reducing sanitary event and quarantine measures. Source: Authors.

In the case where the event is reflected in a demand reduction, the welfare impact of the sanitary event will reduce the overall economic surplus, leaving consumers, domestic producers and foreign suppliers unambiguously worse off. This equilibrium is shown as point B in Figure 2. If forensics or testing at the border is 100\% effective, these health costs or economic surplus impacts can be avoided. If this security can be achieved at a low cost without disrupting foreign supply, the measures will increase economic welfare for all parties involved. If on the other hand, the forensics testing at the border results in the total elimination of imports, the market equilibrium will be point $C$. At $C$, consumers face higher prices to avoid the sanitary issue, the foreign supplier loses the market and is worse off, but the domestic producers are better off due to the higher prices that they can now sell at.

Domestic producers will always gain from the stringent application of SPS issues. Since the domestic producer is competing with imported goods or services, the domestic producer has the incentive to ask for protection. If precaution is enforced by a nation using illegitimate reasoning, this is either political or economic precaution. These precautionary actions stem from societal or economic pressures to take action as a result of low risk or even speculation in order to protect the nation [17]. In 2004, Japan implemented a political precaution that may have been economically beneficial to their domestic beef producers. In the 2000s, bovine spongiform encephalopathy (BSE) was taking a toll on cattle producers around the world, therefore the Japanese government decided to protect their herds by stating that they would not import beef from a nation unless they tested all their animals for BSE before export. Unfortunately, inspecting all meat or animals does not increase protection from BSE, as BSE is only detected in older animals. Therefore, for any nation wanting to trade with Japan, that nation's cost of production would increase by the cost of testing all animals [18].

Under the World Trade Organization's SPS Agreement, these restrictions, bans and precautionary protectionism are all within a gray area, as they can have merit until proven otherwise, and even then enforcing or reprimanding these actions is difficult to follow through on. Since scientific evidence can and will never be conclusive, a nation can always find justification to impose a ban or restriction, given that they cite what risks remain or request further research be conducted [19]. Subsequently, the World Trade Organization (WTO) is also not well equipped to handle restrictions of trade that are a result of consumer protectionism pressures. Given that the WTO's economic model of trade liberalization, consumers benefit in terms of lower prices, but this does not benefit consumers concerns, nations could choose to use this to impose protectionism to benefit their producers at point $\mathrm{C}$ in Figures 1 and 2. 


\section{Pathogens and Detection of Contamination}

With a large number of pathogens and differences in allowable substance for imports around the world, detection in agriculture has become unavoidable. While nations are not frequently taking SPS issues to the WTO dispute settlement mechanism, it does not mean that an increased use of trade disputes will not occur as nations try to protect the health of their domestic agricultural sectors. Since 2000, 413 issues have been raised as SPS disputes spanning food safety (34\%), animal health (34\%), plant health (24\%), and other concerns (88\%) [20]. Of which, 124 were resolved, 30 partially resolved, and the remaining 259 have yet to report a resolution, suggesting that nations may have imposed their own form of protection. Despite the low occurrence of nations outright rejecting or banning imports due to of traces SPS risk, there is reason to suspect this could change. With the advancements of science to more precisely test and detect SPS risks, paired with the potential gains which restricting trade can have on domestic importer prices, it could be possible to see the tightening of SPS risk thresholds by importing nations. With this in mind, this article turns to a discussion of pathogens and SPS risk thresholds the Canadian canola industry has dealt with regarding canola exports.

Canada is the primary global producer and supplier of canola, with a growing demand for bio-based lipids. With the strong potential for market growth, Canada does not want to see a ban or border closure for canola. As described above, Canada has already experienced canola import rejection by China, due to an accusation of blackleg being present in shipments. The reason why importing nations reject shipments with blackleg present is that it is a fungus (Leptosphaeria) that can be difficult to manage as the spores of the fungus affect the plants and leaves that remain in the field, like on stubble. The spores can lay dormant, having the ability to reappear when weather conditions are optimal, and it is suggested that canola not be planted on a four-year rotation to reduce the presence of blackleg spores [21]. However, this cannot stop the airborne spread of spores as they attach themselves to the cotyledons and young leaves of nearby plants, forming a lesion. The lesion allows the fungus to attach to the plant's vascular system, causing the root to rot and create a canker [22]. As a result, if imported seeds have blackleg spores, this could have potentially negative and lasting effects if the imported are used for seed propagation. The use of seed treatments and post-emergence foliar fungicides have proven to be effective tools, yet wet conditions and early blossoming can impair the effects of the chemical [21]. Despite having multiple tools available, in recent years blackleg prevalence in Western Canada has been greater than $50 \%$ of surveyed fields.

Since most of the canola exported from Canada is crushed and used for cooking oil, it would be unexpected to be used for seed production, but this does not mean that any pathogens present would not affect export markets. Knowing this, the Canadian canola industry works hard to control the spread of the pathogen Plasmodiophora brassiciae, this soilborne disease is best known as clubroot. Spores of $P$. brassiciae can lay dormant in the soil for up to 20 years, maintain the ability to infect a brassica host plant through the roots [23]. The disease infects the root system, producing club- or gall-like deformations. Due to the deformed roots, resources are deprived of the rest of the plant, stunting and killing the plant in many cases. Crop losses vary by brassica variety and the strain of clubroot. In Canada, it is estimated that yield losses reach 30\% [24], while in heavily infested fields in other parts of the world, as much as 50\% can be lost [23]. For Canadian canola producers, there is no chemical registered that controls clubroot. Even though clubroot is spread through the soil, spores can attach to the harvested seed. The Canadian Seed Trade Association has not found canola seed to contribute to the spread of clubroot, yet provincial governments emphasize there is a risk of seeds coming into contact with spores from soil dust or earth tag (when soil or small moisture particles from weeds and other plant materials become stuck to the seed) and contaminated shipments $[25,26]$. Given the threat of the spore, potentially trading a crop with traces of the P. brassiciae strain could lead to future contamination of seed stocks in importing nations. 
Another pathogen present in Canada, which could have negative impacts if spread abroad is Phytophthora. Phytophthora is a group of over 100 fungi-like water mould species [27]. This strain of pathogen has adapted to a wide range of plants both agricultural and ornamental and has been connected to the 19th-century Irish potato famine, and currently impacting cash crops such as soybeans [28]. The pathogen is transmitted through the contact of infected plant material, as well as zoospores in water and soil, which can be transmitted through animal or human contact. On top of being easily transmitted, the pathogen can remain dormant for a period of several weeks to several years, until conditions such as temperatures and moisture become ideal to activate the spore, beginning germination.

The impacts of Phytophthora pathogens vary from species to species, but frequently are devastating. In soybeans, $P$. sojae causes the roots and stem to rot, resulting in yield or plant loss. The pathogen is easily transmitted through the soil and can lay dormant, once a field has contracted Phytophthora, farmers must be careful in future rotations to ensure that they do not plant crops susceptible to the pathogen. To combat $P$. sojae and other varieties, there are many fungicides producers can use to help protect seeds and plants for a limited time, as well, they can work to improve drainage and compact soils to help keep the pathogen dormant. Many crop varieties are resistant to Phytophthora. However, no soy variety is resistant to all strains of P. sojae.

For the past 100 years, Canadian farmers have worked to control Fusarium graminearum (F. graminearum), which causes serious head blight in cereals, grasses and corn. Fusarium, a large genus of soil fungi, has many harmless spores, which present both sanitary and phytosanitary risks such as impacts on the health of crops, livestock, and humans. In crops, the pathogen infects the plant through the soil or airborne spores under warm and humid conditions, the spores begin to reproduce, infecting the crop as well as leaving spores behind in the soil. The pathogen spreads through the plant, damaging the yield and causing fusarium damaged kernels. In addition to the phytosanitary losses of fusarium, it also causes the production of sanitary toxins which can be present in both the kernel and the soil [29].

The sanitary risk of Fusarium fungal infection is the production of mycotoxins. Once mycotoxins have been found in the kernel, they cannot be destroyed through further processing such as baking, malting or ethanol production and therefore its presence makes the crop useless for food and beverages or as a feed source for livestock [30]. The best way to combat Fusarium and potential mycotoxins is to grow a resistant variety and to follow proper crop rotations. Seed treatments can be implemented, as can foliar fungicides at early flowering to protect the head of the plant [30]. Despite there being means to treat and prevent Fusarium, Andy Tekauz of Agriculture and Agri-Food Canada explains that "there is no magic bullet as far as control of fusarium is concerned", those who implement a combination of precautions do not avoid the risk of fusarium [31].

Fusarium can be an aggressive fungus, since the 1990s Canadian cereals have lost anywhere from $\$ 50$ to $\$ 300$ million annually, and in the Northern Great Plains and the central US, the cumulative losses were estimated to be $\$ 2.7$ billion from 1998 to 2000 [29]. Not only does Fusarium bear a financial cost on the economy, incidental contamination of globally traded crops and feeds pose sanitary risks, damaging the trust and reputation between trading nations [32].

Lastly, while chemical residues and GM crops are not pathogens, importing nations that have yet to accept GM crops or have banned specific chemicals may use the thresholds for their presence as a reason to reject a commodity shipment. Since the first GM crop approval in the US in 1994, there has been import acceptance and adoption in 71 nations, while there has been rejection in many of the rest. Each nation has the right to approve or reject the cultivation and import for food or feed of any, and all, GM events. While some nations have a zero-tolerance policy for GM crops, others have a maximum level of tolerance for coexistence. If an unapproved GM variety is present in an imported shipment, a nation can claim that it is a threat to their SPS regulations. The same holds for when 
chemical residues exceed a nation's set maximum residue limit (MRL) or there is a residue of an unapproved substance.

For the case of GM crops, there is no scientific evidence that supports them being an SPS threat, yet if a nation feels that the unknown risks are a future threat, they will enforce SPS regulations to protect their population. The risk that unapproved GM varieties do present to importers is the possibility that a GM plant is grown unknowingly and then treated with a chemical not recommended; this could lead to future issues of resistance or lead to breeding of a crop that is not approved for sanitary reasons. It is also similar for residues of chemicals. Each nation has a regulation of what is acceptable for chemical residues, and if the maximum is exceeded, rejection can occur. In 2018, the EU set new MRLs for nearly a dozen chemicals used in the production of fruits, vegetables, tubers, nuts and cereals. In total, 20 nations have taken this to the WTO, as the new MRLS fall below the Codex MRLs, and these nations, including Canada, believe further proof is required to justify these stricter MRLs for crop production chemicals, as it currently appears to be "based on the perceived uncertainty" [33].

While pathogens have plagued crops worldwide since the domestication of plants, humans have intervened to try to eliminate and maintain the risks of SPS concerns. To do so, producers and science have been successful in many cases at minimizing the spread and threat of plant diseases. However, agriculture is not completely able to control the presence of pathogens in commodity shipments.

\section{New Technologies}

Every crop and habitat is threatened by a particular group of pathogens, whether bacterial, fungal, viral or parasitic and as trade increases, there are greater risks of distributing these pathogens. Currently, traces of pathogens have been found in crop shipments such as ergot in wheat and blackleg in canola, which can be damaging to the importing nations' production and health. There are also various standards internationally on the residues and presence of specific crops that are not approved within specific importing nations. So, how can exporters reduce the risk of spreading pathogens, or avoid surpassing the allowable comingling of other crops or MRL, and protect their reputation? Through the use of pathogen testing or certification at the port position. Since the importer is risk averse to specific pathogens, residues, and crops, they can inspect on delivery and impose a trade ban or restriction if any risks are detected. In this scenario, the exporter is better off reducing the likelihood of a pathogen, residue or crop from causing the imposition of a trade ban. One way is by imposing pathogen testing or more advanced forms of residue testing at the export position, much like conducting forensics at the port. Doing so ensures that the exporting nation's shipment cannot be rejected for scientific SPS reasons. Diagnostic testing of pathogens is based on scientific practices, therefore if the test is negative for a pathogen, it is scientifically free of the pathogen and should not be rejected based on science. Shown in Figures 1 and 2, there is economic incentive for an importing country to be protectionist, therefore to provide protection to their domestic suppliers, under diagnostic testing, they would either need to claim non-scientific reasoning for rejection or bans, or use spurious non-scientific reasons to trump the negative pathogen results. As examined in the previous section, trade has been banned and relationships have been damaged as a result of contamination and disease.

As science continues to research crops and the related pathogens, new means of testing for them are being commercialized. Given the importance of commodity trade, it is expected that the demand for quick, easy and cheap tests to verify the SPS standards of crops will continue to grow. This section presents the technologies available for SPS pathogen testing, advantages and disadvantages, as well as the next generation of testing.

Previously, the detection of pathogens relied heavily on the visual assessment by producers, alongside the remote access to pathogen testing which was both costly and time consuming. However, advancements in technology have reduced time and cost, making testing more easily assessable. One such technology is polymerase chain reaction (PCR). 
The first technology to detect or produce DNA on larger scales was PCR, as its testing is highly sensitive and requires only a small portion of the sample [34]. To carry out the test, the sample, along with primers, nucleotides and DNA polymerase are mixed on plates (of 96+ test wells) or in test tubes and run through a cycle of heating and cooling to increase the DNA molecules. Afterwards, the PCR is analyzed through staining the DNA with chemical dye or labelling the primers or nucleotides with fluorescent dyes. The technology is portable and easy to use and is quantifiable, yet there are limits to this ageing technology [35]. PCR results are dependent on the extraction of the sample, it has a number of components needed to carry out the test and testing is limited to the primers available to what can be tested. Portable PCRs are now available and have increased in use, due to the short amount of time of as little as $25 \mathrm{~min}$, whereas PCR performed by a lab technician services takes a day, as shown in Table 1 [36].

Table 1. Fusarium and deoxynivalenol pathogen services.

\begin{tabular}{|c|c|c|c|c|c|}
\hline Detection & Technology & Range & $\begin{array}{c}\text { Time } \\
\text { (Min or Days to Return) }\end{array}$ & $\begin{array}{c}\text { Rate } \\
(\mathrm{CDN} \$)^{*}\end{array}$ & $\begin{array}{c}\text { Sample } \\
\text { (Minimum) }\end{array}$ \\
\hline \multirow{2}{*}{ Fusarium graminearum } & Real-Time PCR (DNA) & & 1 day return & $\$ 56.50$ & $600+$ seeds \\
\hline & Plate & $0.05 \%+$ & 5-7 day return & $\$ 45.50$ & 200 seeds \\
\hline \multirow{4}{*}{$\begin{array}{l}\text { DON (vomitoxin or } \\
\text { deoxynivalenol) }\end{array}$} & LFD Strip ID & $0-8$ ppm & $2-3 \mathrm{~min}$ & & $50 \mathrm{~g}$ \\
\hline & $\begin{array}{l}\text { LFD (Digital Reader } \\
\text { no incl.) }\end{array}$ & 0-12 ppm & $3-5 \min$ & $\$ 9.50$ & $20-50 \mathrm{~g}$ \\
\hline & Mass Spectrometry & & 4 day return & $\$ 1015.74$ & $1-2 \mathrm{~kg}$ \\
\hline & ELISA & $25-250 \mathrm{ppb}$ & $\begin{array}{l}20 \text { min test } \\
3 \text { day return }\end{array}$ & $\$ 295.69$ & $1-2 \mathrm{~kg}$ \\
\hline
\end{tabular}

* Rates based on the most recent publicly available prices, 2017.

Loop-mediated isothermal amplification (LAMP) and reverse transcription loopmediated isothermal amplification (RT-MALP) are diagnostic tools which greatly affect the time and cost of testing. This is because LAMP is able to amplify the DNA rapidly and efficiently using isothermal conditions with a DNA polymerase and set of primers, allowing it to copy the DNA nine times within an hour [37]. While PCR is a technology to offer precise results, the introduction of LAMP offers the ability to perform a highly sensitive and rapid method. According to Wang et al. (2014), in comparison to a multiplex PCR, LAMP methods can be as high 1000-fold more sensitive [38]. The agriculture industry is already exploring the use of LAMP for aphids, as a particular species (TuYV) offer a great risk to the Australian canola industry [39]. Being able to rapidly test for their presence using LAMP, allows farmers to quickly identify whether the aphid has migrated, allowing them enough time to spray and contain the risk. Outside of their use in agriculture, the low cost, portability, and the ability to be highly specific in a short time period has led LAMP to be a reliable method for rapidly diagnosing COVID-19, as using PCR requires more time and great resources such as laboratories and technicians which during the pandemic is not sufficient solution [40].

Another technology widely used today is ELISA, enzyme-linked immunosorbent assay. In this test, a microtiter plate of wells is used to identify specific antigens. Each of the plate wells is coated with the antibody of interest and filled with a diluted sample of the item being tested, such as a wheat kernel. If the toxin, or antigen, is present in the sample it will bind with to the antibody attached to the plate wells. After this there are multiple steps which involve washing the plate to remove any sample or toxin that has not bound to the well, adding another solution of antibody coupled with an enzyme, which will only bind to the toxin already bound to the plates' antibody, the plate is rinsed again, antibodies and enzymes will only remain if they have bound to a toxin. If there are no toxins in the sample, no enzymes will be left on the plate. It is this enzyme that will react with a chromogenic substrate solution, creating a visual color change which can be identified by 
the test operator or quantified by an electronic plate reader [41]. Currently, ELISA offers lower-sensitivity testing for bacteria and the results are more of a confirmation rather than a quantification [35]. This test can quantify the percentage of toxin or pathogen present due to the use of wells for two-fold dilution. Each row of wells tests a greater dilution of the sample, which allows the detection of a percentage or part per unit measurement. Table 1 shows that ELISA offers one of the more sensitive tests available, yet requires both a larger sample and is a more expensive test.

Gas chromatography-mass spectrometry (GC-MS) is the combination of gas chromatography and mass spectrometry, commonly used in forensics and medical diagnostics. In GC-MS a solution sample is vaporized and then sent through a chromatographic column where it is separated by compounds, the molecules are then fragmented by electrons and ionized to be counted by their mass [42]. This process provides high specificity and detects pathogens at various stages [35]. The shortcoming of this technology is that the step-up and processing time is lengthier than other diagnostics, and it is not portable, therefore only a limited number of companies have invested in this technology by offering plant pathogen testing services.

The cheapest and easiest detection method so far is the lateral flow tests (LFD), which uses immunochromatography [43]. It is a strip dipstick, with a dry reagent that indicates either positive or negative when the dry reagent is activated or not by the fluid sample. The most obvious example of an LFA is a pregnancy test which can verify but cannot quantify. These strip tests can be performed anywhere along the supply chain, from the field to the vessel, and take only minutes to conclude. The advantage of the LFD is that it is both a quick and inexpensive test, which requires only a small sample of less than $50 \mathrm{~g}$. The disadvantage is that you get what you pay for. At less than $\$ 10$ a test, the accuracy of testing ranges from 0 to $8 \mathrm{ppm}$, so a test may come up $0 \mathrm{ppm}$. However, when tested using ELISA, it can detect as little as $0.025 \mathrm{ppm}$, and in trade $0 \mathrm{ppm}$ and $0.025 \mathrm{ppm}$ could be the difference between open and closed trade.

Research regarding current detection techniques is ongoing, trying to improve in size, time and cost, through nanodiagnostics. The objective is to create a process and product that can test and sequence DNA molecules individually, which is fast, portable and highly sensitive (earlier detection) [36]. Testing at the nanolevel requires smaller samples and offers greater accuracy of sensitivity. A few nanodiagnostics technologies being used for plant pathogens are nanosensors, quantum dots $(\mathrm{QD})$, gold nanoparticles and bio-barcoded DNA ( $b$-DNA). Nanosensors conduct electrically through polymers that can detect low levels within a few minutes, which could benefit the movement of precision agriculture. The QD technology uses inorganic fluoresce semiconductor nanoparticles, which offer an advantage over organic fluoresce and the need to have visual protein detection and nucleic acid markers. Gold nanoparticles are markers that can identify pathogens optically or electrochemically. Finally, $b$-DNA uses oligonucleotide-magnetic gold nanoparticles, which allows for ultrasensitive analysis. As a result of nanotechnology offering a higher limit of detection, this form of testing will likely continue to grow and change how the industry quantifies and assesses the pathogens and our understanding of the pathogens themselves.

When it comes to testing for a pathogen there are options, it is dependent on who is testing, the level of confirmation needed, and the budget of time and money. For instance, a farmer is not likely to have a GC-MS machine to test for a pathogen or MRLs, as their crop is being blended with others before export. Canadian exporters and the Canadian Grain Commission (CGC), which tests every export shipment, will have the more expensive, more advanced machinery to ensure that what leaves the port is meeting the standards of the importer.

\section{Policy Implications}

Each nation has its trade policies and verification of grading, quality, and safety, which poses a threat to importing nations. Given the variance of standards and policy of trading nations, this creates the opportunity for misrepresentation to occur or for contaminants to 
be exchanged within in supply chain. As shown in Figure 3 and by Ge et al. [44], there are times in the grain supply chain in which the product can be tested to increase traceability and reduce the risks of SPS or misrepresentation of exporting suppliers. In the simulation research by Ge et al., testing and tracing strategies were proven to both efficiently reduce the occurrence of contamination and misrepresentation, as well as keep handling costs low [44]. This suggests that imposing a policy for improved pathogen and grading could not only benefit the export standards of a nation and its trade, but it may also be able to do so without hefty costs to the supply chain.

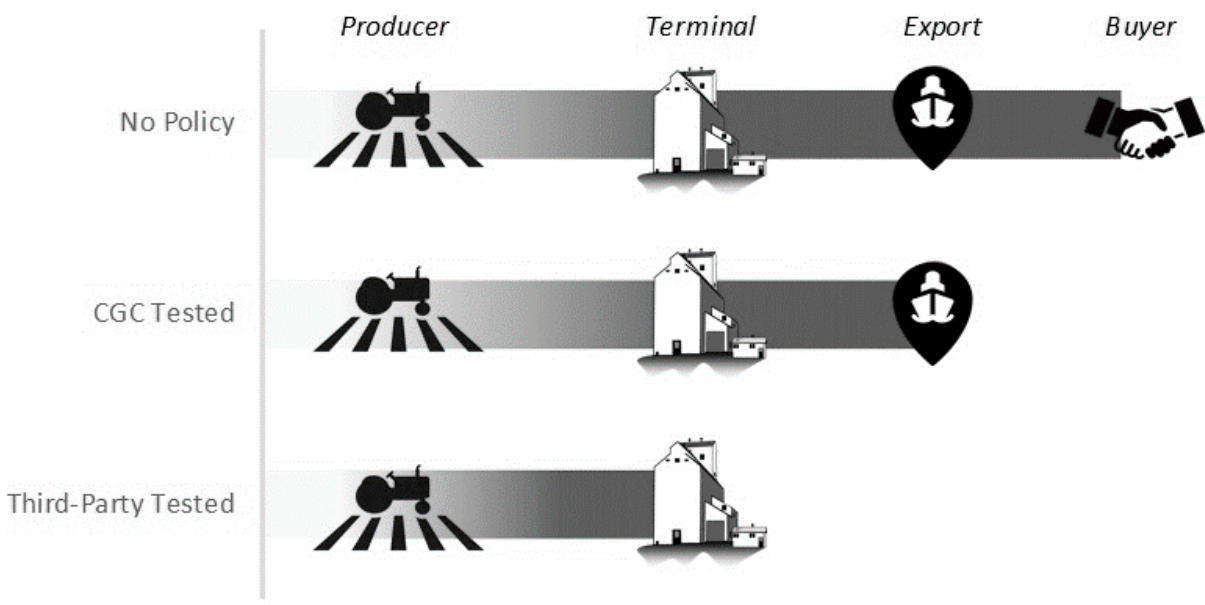

Figure 3. Risk of rejection under a diagnostic policy. Source: Authors.

Investment in pathogen testing is increasing as cost drops and as they become portable and easier to use. Currently, diagnostic services offer producers assurance when selling their product. However, they are not required at the point of sale, putting inspection, ownership and risk on the purchaser. To reduce pathogen risk and possible rejections, bans or exporter incurred costs, governments could impose plant pathogen and residue testing before export. In other words, conducting plant diagnostic verification at the port position. With such a policy, there comes both benefits and costs to the agriculture market.

First, by enforcing pathogen testing at the port position, scientific transparency is established between buyers and sellers. Pathogen testing ensures that what is being sold meets the SPS standards of the buyer. This should remove the risk of an importing nation claiming an SPS risk. Such transparency should reduce the occurrence of shipments being rejected, helping to keep commodities moving at point A of Figures 1 and 2. Given that the cost of testing products is less than the cost of rejection, point $C$, there is an economic benefit for the exporting position imposing such a diagnostic policy of plant pathogens.

While transparency is assumed to be a positive attribute, it could lead to negative or constricting implications. There is a chance that increased transparency will drive importing nations to increase their SPS standards. However, to be able to do so and remain compliant with their WTO obligations, a nation has to have scientific justification for any SPS change. While a nation may have previously allowed a LLP of a substance or pathogen, with improved pathogen testing, a nation can revise standards and reduce tolerance thresholds. If Canada began testing all canola for blackleg or clubroot before export, an importing nation may choose to reduce a $1 \%$ tolerance to $0.05 \%$. Reducing LLP and acceptable tolerance will change how commodity sellers blend their products, which will likely reflect in a marginally higher export market price.

Imposed plant pathogen testing can signal both a safe product and build a stronger reputation for the exporting market. If the product which has been tested for pathogens is found to be under the maximum level of tolerance, this should signal it as both a safe and premium product. With the gains in safety and reputation, an exporter may be in the position where either buyers are willing to pay a premium for the reassurance of a safe product, or they will not find these to be a benefit and will not pay for it, lowering the 
demand to $\mathrm{D}_{\mathrm{D}}$ of Figure 2, and resulting in a lower price at point $\mathrm{B}$, which is not beneficial to the exporters' position.

There are several scenarios where plant pathogen diagnostic policy could impact domestic business, price and risk. As demonstrated in Figure 3, there are three primary instances. First, if the policy is not imposed, trade remains where it is, and commodities move from farmer to elevator, to the port position to the final buyer. If no policy is imposed, the commodity can move through the supply chain and once it reaches the import buyer position it can either be accepted or rejected. The commodity should only be rejected if the buyer inspects the commodity and finds that it does not meet SPS standards, in which case this risk falls on the exporter. Since crop commodities are sold and transported in bulk, there is minimal ability to trace which farm or elevator the non-compliant SPS shipment came from, and therefore the exporter bears this risk. As an exporter, if this risk is great enough, it may lead them to support mandatory diagnostic testing for specific plant pathogens and residues.

Were plant pathogen testing to become mandatory, there are two likely scenarios, either the government, the CGC in the Canadian case, would regulate and implement the diagnostics, or they would allow third parties to offer this service under their standards/certification. When the government enforces testing, they will not approve export shipments without testing, removing the buyers' risk of SPS rejection for the tested pathogens. If the government is carrying out the testing, they can do so anywhere along the supply chain. Crops that are not tested until reaching port position bear the risk of not being able to identify where the grain exactly came from. The grain may have been blended at the inland terminal position. Whereas if they enforce testing on delivery to the terminal, it puts all the risk of rejection or reduces prices on the producer.

A policy that allows for third-party companies to perform diagnostics creates a competitive model for agronomy services. Third-party testing would likely be mandated to occur before or at the delivery to the inland terminal. This puts the risk of having a commodity rejected entirely by the producer. In this scenario, every delivery or field would need to be tested, which drives the price up to a premium or cuts the producer's profits. Enforcing testing at the producer level may both impact their reputation and their future profits. Third-party services also create a competitive market which will need to be regulated and inspected to ensure that standards stay in place as these services compete with one another over lower prices, turn-over of results and precision testing. These competitors will want to keep costs down, which will help drive the innovation of diagnostic tests and the need for expensive equipment, machinery, and skilled lab technicians.

\section{Conclusions}

Scientific advances in the ability and accuracy of commodity testing are on the cusp of dramatically altering how commodity trade is undertaken. Genomic diagnostics could completely alter the off-type thresholds that have evolved in commodity trade and have become increasingly lower over decades. The transformation in testing accurately at parts per billion and potentially parts per trillion certainly offers nations the opportunity to manipulatively apply SPS standards in a veiled protectionist attempt.

It seems that there is a need by the exporting position to impose these biotechnological and diagnostic tests before the goods leave the port position. Theoretically, improved diagnostic testing before export should support safe and trusted trade, and prevent risks of contamination from SPS pathogens, residues or off-types. Moving forward, the question would seem to be: who will implement and manage pathogen testing? The grain industry has successfully managed commodity shipments weekly and may well be best positioned to continue with this as the commodity world moves into genetic testing for SPS concerns. However, the grain trade industry does not have the mandate to bring a case of trade distortion to the WTO when a nation is flouting the existing SPS Agreement. Complaints may only be brought to the WTO by national governments. For this reason, it may be best for the CGC to extend its existing export verification testing to include genetic pathogen testing. 
Regardless of the management issue, the brunt of the burden is ultimately going to reside with producers. Considerable thought needs to be given on how to ensure that producers are not unfairly economically disadvantaged for factors that in many instances are largely beyond their control. Producers have proven that they are capable of meeting production standards with very low comingling thresholds for off-types, but one area of profitability for the grain trading industry is to blend off-types to exactly meet contract specifications. If producers deliver a commodity that is pathogen free, a grain handler could blend in the pathogen-infected grain into this clean grain. The system put in place needs to ensure that liability lies where it belongs, as failure to do so will further undermine producers' confidence in the grain handling system, which is marginal at the best of times. Given the current trade environment, it appears that importer nations have the power to reject goods based on safety precautions, and are willing to use it even without confirmed science-based evidence. This environment puts greater responsibility on producers and grain terminals to ensure the accuracy and safety of crops in attempts to defend goods to international consumers and potentially protect their profits.

Author Contributions: Conceptualization, S.J.S. and R.S.G.; Methodology, Formal Analysis and Visualization, S.W.G. and R.S.G.; Writing, S.W.G., R.S.G. and S.J.S. All authors have read and agreed to the published version of the manuscript.

Funding: This research was funded by a grant from the Alliance for Food and Bioproducts Innovation program.

Informed Consent Statement: Informed consent was obtained from all subjects involved in the study.

Data Availability Statement: Data sharing not applicable.

Conflicts of Interest: The authors declare no conflict of interest.

\section{References}

1. Temple, L.; Chiffoleau, Y.; Touzard, J. A history of innovation and its uses in agriculture. In Innovation and Development in Agricultural and Food Systems; Faure, G., Chiffoleau, Y., Goulet, F., Temple, L., Touzard, J., Eds.; Éditions Quae: Versailles Cedex, France, 2018.

2. Smyth, S.J.; Phillips, P.W.; Castle, D. Handbook on Agriculture, Biotechnology and Development; Edward Elgar Publishing Led.: Cheltenham, UK, 2015.

3. Gonsalves, C.V.; Gonsalves, D. The Hawaii papaya story. In Handbook on Agriculture Biotechnology and Development; Smyth, S.J., Phillips, P.W.B., Castle, D., Eds.; Edward Elgar Publishing Ltd.: Cheltenham, UK, 2014; pp. 728-751.

4. Isaac, G.E.; Kerr, W.A. Genetically modified organisms at the World Trade Organization: A Harvest of Trouble. J. World Trade 2003, 37, 1083-1095.

5. Hobbs, J.E.; Kerr, W.A.; Smyth, S.J. How Low Can You Go? The Consequences of Zero Tolerance. AgBioForum 2013, 16, $207-221$.

6. Kalaitzandonakes, N.; Phillips, P.W.B.; Wesseler, J.; Smyth, S.J. The Coexistence of Genetically Modified, Organic and Conventional Foods; Springer Science+Business Media: New York, NY, USA, 2016; p. 426.

7. University of Kansas. Biosecurity reduces invasions of plant pathogens over a national border. ScienceDaily, 31 May 2018.

8. Hobbs, J.E.; Kerr, W.A.; Smyth, S.J. The perils of zero tolerance: Technology management. Int. J. Technol. Gloablisation 2014, 7, 203-216. [CrossRef]

9. Atici, C. Low Levels of Genetically Modified Crops in International Food and Feed Trade: FAO International Survey and Economic Analysis; FAO: Rome, Italy, 2014.

10. High Court of Australia, Perre v Apard Pty Ltd. 198 CLR 180; Perre v Apard Pty Ltd.: Canberra, Austalia, 1999.

11. Fernando, W.G.D.; Zhang, X.; Amarasinghe, C.C. Detection of Leptosphaeria maculans and Leptosphaeria biglobosa Causing Blackleg Disease in Canola from Canadian Canola Seed Lots and Dockage. Plants 2016, 5, 12. [CrossRef] [PubMed]

12. Johnson, K. Ottawa has work cut out in solving China's canola import issues. Western Producer, 18 August 2016.

13. Leblanc, D. China does not want canola dispute on agenda during Trudeau's visit. The Globe and Mail, 26 August 2016.

14. Noakes, S.; Burton, C. Economic Statecraft and the Making of Bilateral Relationships: Canada-China and New Zealand-China Interactions Compared. J. Chin. Political Sci. 2019, 24, 1-21. [CrossRef]

15. Elmer, K. China defends ban on Canadian canola, saying it reported pest problem on four occasions. South China Morning Post, 30 March 2019.

16. Lindsay, J.M. Trade Sanctions as Policy Instruments: A Re-Examination. Int. Stud. Q. 1986, 30, 153-173. [CrossRef]

17. Kerr, W.A. Sanitary Barriers and International Trade Governance Issues for the NAFTA Beef Market. In Keeping the Borders Open, Proceedings of the Eighth Agricultural and Food Policy Systems Information Workshop; Loyns, R.M.A., Meilke, R., Knutson, R.D., Yunez-Naude, A., Eds.; University of Guelph: Guelph, ON, Canada, 2004; pp. 26-29. 
18. Loppacher, L.J.; Kerr, W.A. The Efficacy of World Trade Organization Rules on Sanitary Barriers: Bovine Spongiform Encephalopathy in North America. JWT 2005, 39, 427-443.

19. Kerr, W.A.; Hobbs, J.E. Consumers, Cows and Carousels: Why the Dispute over Beef Hormones Is Far More Important than Its Commercial Value; Perdikis, N., Read, R., Eds.; Edward Elgar: Cheltenham, UK, 2005; pp. 191-214.

20. WTO. Sanitary and Phytosanitary Information Managment System STC Reports; WTO: Geneva, Switzerland, 2020.

21. Government of Saskatchewan. Blackleg of Canola. 2017. Available online: https://www.saskatchewan.ca/business/agriculturenatural-resources-and-industry/agribusiness-farmers-and-ranchers/crops-and-irrigation/crop-protection/disease/blacklegof-canola (accessed on 17 April 2017).

22. Marcroft, S.; Bluett, C. Blackleg of Canola. May 2008. Available online: http://agriculture.vic.gov.au/agriculture/pests-diseasesand-weeds/plant-diseases/grains-pulses-and-cereals/blackleg-of-canola (accessed on 18 April 2017).

23. Dixon, G.R. The Occurrence and Economic Impact of Plasmodiophora brassicae and Clubroot Disease. J. Plant Growth Regul. 2009, 28, 194-202. [CrossRef]

24. Tewari, J.P.; Strelkov, S.E.; Orchard, D.; Hartman, M.; Lange, R.M.; Turkington, T.K. Identification of clubroot of crucifers on canola (Brassica napus) in Alberta. Can. J. Plant Pathol. 2005, 27, 143-144. [CrossRef]

25. CSTA. Clubroot. Available online: http://cdnseed.org/archive/pdfs/Fact\%20Sheets/ClubrootFactSheet.pdf (accessed on 18 April 2017).

26. Alberta Clubroot Management Committee. Alberta Clubroot Management Plan. 2014. Available online: http:/ /www1.agric.gov. ab.ca/\$department/deptdocs.nsf/all/agdex11519/\$file/140-638-2_WEB.pdf?OpenElement (accessed on 18 April 2017).

27. Kay, J.; Meijer, H.J.G.; ten Have, A.; van Kan, J.A. The aspartic proteinase family of three Phytophthora species. BMC Genom. 2011, 12, 1-15. [CrossRef]

28. Tyler, B.M.; Cohen, G.L.; Garcia, J.; Apfel, N.; Master, A. Phytophthora Genome Sequences Uncover Evolutionary Origins and Mechanisms of Pathogenesis. Science 2006, 313, 1261-1266. [CrossRef] [PubMed]

29. Alberta Fusarium Action Committee. Alberta Fusarium Graminearum Management Plan; Alberta Agriculture and Rural Development: Edmonton, AB, Canada, 2015.

30. Government of Saskatchewan. Fusarium Head Blight. 2017. Available online: https://www.saskatchewan.ca/business/ agriculture-natural-resources-and-industry / agribusiness-farmers-and-ranchers/crops-and-irrigation/crop-protection/ disease/fusarium-head-blight (accessed on 18 April 2017).

31. G3 Canada Limited. Managing Fusarium Head Blight; G3 Canada Limited: Winnipeg, Canada, 2011.

32. Placinta, C.M.; D'Mello, J.; Macdonald, A. A review of worldwide contamination of cereal grains and animal feed with Fusarium mycotoxins. Anim. Feed Sci. Technol. 1999, 78, 21-37. [CrossRef]

33. WTO. STC Number-448; WTO: Geneva, Swizterland, 2020.

34. Garubyan, L.; Avashia, N. Polymerase Chain Reaction. J. Invest. Dermatol. 2013, 133, 1-4. [CrossRef] [PubMed]

35. Fang, Y.; Ramasamy, R.P. Current and Prospective Methods for Plant Disease Detection. Biosensors 2015, 5, 537-561. [CrossRef] [PubMed]

36. Khiyami, M.A.; Almoammar, H.; Awad, Y.M.; Alghuthaymi, M.A.; Abd-Elsalam, K.A. Plant pathogen nanodiagnostic techniques: Forthcoming changes? Biotechnol. Biotechnol. Equip. 2014, 28, 775-785. [CrossRef]

37. Notomi, T.; Okayama, H.; Masubichi, H.; Yonekawa, T.; Watanabe, K.; Amino, N.; Hase, T. Loop-mediated isothermal amplification of DNA. Nucleic Acids Res. 2000, 28, E63. [CrossRef]

38. Wang, X.; Seo, D.J.; Lee, M.H.; Choi, C. Comparison of conventional PCR, multiplex PCR, and loop-mediated isothermal amplification assays for rapid detection of Arcobacter species. J. Clin. Microbiol. 2014, 52, 557-563. [CrossRef]

39. Congdon, B.; Matson, P.; Begum, F.; Kehoe, M.; Coutts, B. Application of Loop-Mediated Isothermal Amplification in an Early Warning System for Epidemics of an Externally Sourced Plant Virus. Plants 2019, 8, 139. [CrossRef]

40. Thompson, D.; Lei, Y. Mini review: Recent progress in RT-LAMP enabled COVID-19 detection. Sens. Actuators Rep. 2020, 2, 100017. [CrossRef]

41. Gan, S.D.; Patel, K.R. Enzyme Immunoassay and Enzyme-Linked Immunosorbent Assay. J. Invest. Dermatol. 2013, 133, 1-3. [CrossRef]

42. University of Bristol. Gas Chromatography Mass Spectrometry (GC/MS); Elsevier: Bristol, UK, 2008.

43. Danks, C.; Barker, I. On-site detection of plant pathogens using lateral-flow devices. EPPO Bull. 2000, 30, 421-426. [CrossRef]

44. Ge, H.; Nolan, J.; Gray, R. Identifying Strategies to Mitigate Handling Risksin the Canadian Grain Supply Chain. Can. J. Agric. Econ. 2015, 63, 101-128. [CrossRef] 